\title{
IN CELEBRATION OF PROF. DR. SÁNDOR ORBÁN: A TRIBUTE TO 45 YEARS IN BRYOLOGY
}

\section{Erika Pénzes-Kónya*, Tamás Pócs \& Andrea Sass-Gyarmati}

Eszterházy Károly University, Institute of Biology, Department of Botany and Plant Physiology; H-3300 Eger, 6th Leányka street, Hungary;

*E-mail: konya.erika@uni-eszterhazy.hu

Sándor Orbán was born on the 3rd of November 1947 in Nyíregyháza, Hungary, where he completed his elementary and secondary school studies. He graduated from Pál Vasváry Secondary school in 1966 and was admitted to the Biology Programme of the Natural Sciences Faculty of Eötvös Lóránd University (ELTE-TTK) Budapest the same year. He completed the programme and obtained a degree in 1971. In 1979 he enrolled again in Eötvös University as a correspondence student to obtain certification as Biology teacher the following year.

During his university years he developed an interest in Botany and participated in the research projects in the field station of Plant Taxonomy and Ecology Department at Csévharaszt under the supervision of Prof. Tibor Simon. He came out third at the National Scientific Student Conference in Szeged and published two articles from these projects.

He defended his doctoral degree in 1974 on the "Taxonomical revision of species of the Mniaceae family", and was granted a degree by ELTE-TTK. After graduation he was employed by Hungarian Natural History Museum in the Botanical Collection. It was here, that he began to study bryophytes and had the fortune of being taught by well-known experts Dr. Ádám Boros and László Vajda, whose work defined his later scientific career. By 1975 the team had set up a bryophyte herbarium, accommodated the Boros herbarium and arranged several exhibitions. One remarkable exhibition titled Healing Herbs was scripted solely by Orbán.

Along with research colleagues from the Natural History Museum, he participated in the research of Hortobágy National Park, where he conducted studies of bryophyte vegetation 
dynamics, ecology and phenology and floristics. Three scientific articles and a chapter describing the bryophyte flora of Hortobágy were published based on these studies. At the suggestion of Prof. Tamás Pócs (who had offered his personal collection for study) Orbán began processing and revising species of the Calymperaceae moss family with African distribution.

After the death of Ádám Boros, per request of the editors of the journal Revue Bryologique, between 1974 and '77 he refereed Bryological publications from the Central European region. From 1975 to '76 he was the editor of the journal Studia Botanica Hungarica. In 1976 he acceped the invitation of Tamás Pócs to join the Teachers' Training College in Eger, where he soon became assistant Professor, teaching plant taxonomy for nearly forty years.

In addition to teaching he continued research with increasing focus on ecology and taxonomy of tropical mosses. In 1984 he defended his candidate dissertation titled "A Magyarországi mohák stratégiáinak ökológiai összefüggései" (Ecological relationships of the life strategies of Hungarian bryophytes) at the Hungarian Academy of Sciences. He is appointed senior lecturer at the College in the same year. He won College competition with compilation of Instructional Materials for Plant System Education and authors the chapter Tours in the Bükk Mountains for a Guide to Excursions for Primary and Secondary School Students.

In 1978 he was the head-organiser of the Central and Eastern European Bryological Working Group and arranged their first conference of the organisation in Eger. The conference has been held biannually ever since in various locations. It was held in Eger again in 1985 and 1993 as part of the IAB Congress and CEBWG Conference. The presentations of the conference in 1985 were published in Abstracta Botanica journal edited by him and János Podani.

The first results of the revision on the African members of genus Syrrhopodon (Calymperaceae) were published between 1977 and '81. In 1979 Orbán participated in a botanical field-trip to the Spitzbergen, expanding the collection with 150 vascular plants and 200 bryophytes.

In 1983 his book "Magyarország mohaflórájának kézikönyve" (Handbook of Hungarian Bryophytes) co-authored by László Vajda was published. 
The significance of the volume has shown by its nearly two hundred independent citations. He published many paper from his life strategy investigations and taxonomical revisions.

In 1986 and 2005 he received an OTKA (Hungarian Science Foundation) grant for the examination of the indicator values and strategies of bryophytes. During his educational activity he introduced many new, modern scientific subjects in the Department as Exotic Medicinal and Culinary Plants (higher level programmes); Introduction to Biology, Ecology, Biomathematics, Bryology and Micology (basic level programmes); Ecology and Plant Resources and Risks (Master courses); General Bryology, Hungarian Mosses and Modern Ecological approaches in the Environmental Education (PhD courses).

In addition to teaching and scientific work at the department Orbán took part in the College's administration as Deputy General Director from 1981-89, where he was first responsible for the coordination of educational tasks and later (in 1985) he became the Deputy General Director for Scientific Matters. During this time the requirements emphasized that all lecturers must perform in scientific research and acquire scientific qualifications.

This aspiration has also been included in the promotion and appointment requirements. From 1989 to 1994 as Director he became the chief executive of the institution. This was not an easy position during the change of political regime; the tasks included managing structural changes, facilitating the processes of democratisation and liberalisation, drawing up new organisational and operational codes, establishing a party-neutral institution, and the preparation of the new Higher Education Law. His first undertaking was the changing of the name of institution to Eszterházy Károly College. The next major achievements were: the acquisition of the entirety of building „B” for the institution; the agreement on the permanent use of the Líceum building with the Eger archbishop of the Catholic Church, and the initiation of negotiations leading to the College earning University status.

During his time as General Director the development of the Natural Science Faculty on Almagyar Hill had begun by the completion of the new "D" building in which the Biology Institutions, the collections and the Natural Sciences Library were settled, creating a new Campus for the Natural Sciences on Leányka street. 
From 1991 to 1994 he took part in the development of teacher education reform as the President of the General Director's College. Due to the changes in legislation he did not apply for the extension of his term to be succeeded by Éva Zám. He was re-appointed as Deputy Director-General to direct the College's scientific work, where his main task was to increase lecturers'publication rate and ensure their acquisition of scientific qualifications.

In 1998 he was appointed as the Head of the Institute of Biology and Environmental Science which consisted of four departments, he was also elected Head of the Botany Department. He became General Director of the newly established Faculty of Natural Sciences and later its dean for a shorter period in 2006. He was the Director of the newly founded Biological and Geographical Institute between 2007 and 2010.

He was habilitated as University Professor at the Janus Pannonius University, Pécs in 1996. As part of his educational and research activity he has so far tutored and supervised 55 theses and Scientific Students' Association papers.

Ten of his students came out in the first three places at National Students' Association Conferences. Many of his students became employees of the College continuing the research of bryology as: András Vojtkó College Professor, Zoltán Marschall Assistant Professor, Erika Pénzesné Kónya Associate Professor, Sándor Dulai College Professor, László Vizslán Adjunct Professor, Gabriella Kis Scientific Associate and Andrea Sass-Gyarmati, Research Associate - they have become employees of the College and continue bryological research at the College (now University). As external consultant he supervised Gusztáv Jakab's Master and István Galambos' PhD dissertation.

Two of his PhD students, have successfully defended their dissertation recently: Erika Pénzesné Kónya in 2008, and Andrea Sass-Gyarmati in 2015.

$\mathrm{He}$ is currently supervising the work of three students while teaching at the Doctoral School of Environmental Education. In the past forty years he has taken part on fourteen major collection trips and scientific expeditions, which in chronological order were: Semenic Mountains (1972), Retezat Mountains (1974), Spitzbergen (1979), Tanzania - East Africa (1989), USA, Phoenix (1991), Seychelles (1993), Reunion and Madagascar (1994), Reunion (1996), Transylvania and Moldova (2002), Venezuela (2005), India 
(2007), Brazil (2008, 2011) and Mauritius (2016). During the above field-trips, he has collected about eight thousand bryophyte specimens, which after identification were deposited in larger Hungarian herbaria. From the tropical collections he identified many specimens of the Calymperaceae family, more than two thousands of which are now precious elements of our collection. He has held forty presentations at national and international scientific conferences and presented several posters on the results of his research.

He has been the Editor of several Journals and conference publications, such as the Acta Academiae Pedagogicae Agriensis. He is currently a member of the Editorial Board of the Acta Botanica Hungarica and Acta Biologica Plantarum Agriensis Journals. More than 165 pieces of his work have been published in Hungarian and in foreign languages 136 of which are papers and articles, 10 books or chapters and 19 popular science and other publications The number of independent references to his published work exceed 500. Of his books the most significant are "Magyarország mohaflórájának kézikönyve" (Handbook of Hungarian Bryophytes), co-authored with László Vajda and the textbook "Általános Briológia" (General Bryology) published in 1999.

$\mathrm{He}$ is a member of several Hungarian and international scientific associations such as the Hungarian Biological Society, the Botanical Committee of the Hungarian Academy of Sciences (MTA), the International Association of Bryologists, the American Bryological Society, as well as the International Association of Endangered Bryophytes. He is vice-president of the Miskolc Academic Committee since 1988, and president of the Bugát Pál Society for Dissemination of Scientific Knowledge (Bugát Pál Tudományos Ismeretterjesztő társaság - TIT) since 1991.

He was elected as a board member of the National Accreditation Committee and as member of the Scientific and Higher Education Council in 1997. In 2003 he became the member of the Hungarian Accreditation Committee's (MAB) Biological Commission; he was elected as member of the Natural Sciences Advisory Board by the Hungarian Rectors Conference (MRK). In 1994 he and his family moved to Felsőtárkány, a nearby village where fellow professor Tamás Pócs also lives since 1991. In 1996 joining in the active life of the village together with locals they founded a hiking association named after the indigenous Lady's Slipper Orchid (Boldogasszony 
Papucsa Természetjáró Egyesület) of which Orbán was president of for nearly a decade. The association is still active and Orbán participates in its events as a member.

He was a principal investigator of many research grants founded by Hungarian Scientific Research Fund (OTKA), Pro Renovada Cultura Hungariae, MKM, K+F, National Reserch, Development and Innovation Office (NKFP), and other competitions for research and development text-book production. Orbán submitted his Doctor of Science thesis "Taxonomical monograph of the African species of the Calymperaceae family" to the the Hungarian Academy of Sciences on 26 February 1999. Based on a disclosed debate of Doctoral Council within the MTA (Hungarian Academy of Sciences) on the 28 April 2000, he was awarded the title Doctor of the Academy.

Throughout his career he had been awarded numerous other distinctions such as Ministerial Prize in 1975, Award for Excellent Work in 1986, Pro Academia Pedagogica Agriensis in 1993, Excellent Partner in Education in 1994. The highest of them all were the Apáczai Csere János Award which he received in the Ethnographic Museum in 1995. He also received the Eszterházy Károly Memorial Plaquette in december of 1996, the Széchenyi Scholarship for the period of 1997-2001, TIT Bugát Pál medallion in 1998.

In 2003 he recieved the Szent-Györgyi Albert award. In 2010 he received the Scientific Award of the MAB (Miskolc Scientific Committee) and in 2011 the Kiss Péter Award.

Among the above, the most prestigious is the Szent-Györgyi Albert Prize, awarded for his high-level scientific research work and science-management. In addition to his scientific and professional work, it is important to mention his family life In 1973, he married Ágnes, who still is a faithful companion and has helped his work in many ways. She took part in several scientific expeditions (Seychelles, India, Venezuela, Braziland Mauritius) and helped to prepare the collected materials. They have two sons, now adults: His older son is a pharmacist and was awarded a PhD by ELTE University. He has three sons: Bence is ten, Márton is eight, and Áron six years old. His younger son is a musician and he is a qualified music instructor. He acquired his qualification at the gordon department of the Liszt Ferenc Academy. He currently plays the double bass. 
Sándor Orbán has retired and recently works as university professor of Eszterházy Károly University, Eger.

\section{BIBLIOGRAPHY OF SÁNDOR ORBÁN}

\section{2}

ORBÁN, S. (1972). Seasonal changes of assimilating surface and chlorophyll content in Festucetum vaginatae and Secaletum cultum communities. Acta Agronomica 21: 418-428.

SIMON, T. \& ORBÁN, S. (1972). Untersuchungen der Assimilationsflache und des Chlorophyllgehalts des Festuca vaginata Rasens und der Roggensaat. Annales Universitatis Scientiarum Budapestinensis 14: 165-167.

\section{3}

ORBÁN, S. \& DeBRECZY, Zs. (1973). Moos-arealgeographische Studien aus dem Gebiet der Karpaten und Karpatenbecken I. Studia Botanica Hungarica 8: 65-98.

\section{4}

ORBÁN, S. (1974). A Mniaceae család fajainak elterjedése a Kárpátok és a Kárpát-medence területén. Doktori értekezés, Budapest, ELTE TTK, 161 p.

ORBÁN, S. (1974). Moos-arealgeographische Studien aus dem Gebiet der Karpaten und Karpatenbecken II. Studia Botanica Hungarica 9: 43-70.

\section{5}

Bakalár, I., Orbán, S., Pócs, T., Suba, J. \& VARGa, L. (1975). Adatok a Tarnavidék mohaflórájához (Data to the moss flora of the Tarna country). Studia Botanica Hungarica 10: 111-114.

ORBÁN, S. (1975). Moos-arealgeographische Studien aus dem Gebiet der Karpaten und Karpatenbecke III. Studia Botanica Hungarica 10: 63-109.

\section{6}

Borosné-KenYERES, J. \& ORBÁn, S. (1976). Dr. Boros Ádám (1900-1973) publikációinak jegyzéke. Studia Botanica Hungarica 11: 107-119.

JÁRAI-KomlóDI, M. \& ORBÁN, S. (1976). Spore morphological studies on recent European Encalypta species. Acta Botanica Hungarica 21: 305345.

ORBÁN, S. \& PóCS, T. (1976). Rhodobryum ontariense (Kindb.) Kindb. in Central Europe. Acta Botanica Hungarica 22: 437-448.

ORBán, S. (1976). A Riccia gougetiana Mont. és más érdekes Riccia fajok a Hortobágyon. Botanikai Közlemények 62: 197-201. 
ORBÁN, S. (1976). Moos-arealgeographische Studien aus dem Gebiet der Karpaten und im Karpatenbecken IV. Studia Botanica Hungarica 11: 4981.

SzujKó-LaczA, J., Kováts, D., Orbán, S., Verseghy K., Komáromi, Zs. \& Hajdu, L. (1976). Néhány egyszerű módszer a Hortobágyi Nemzeti Park növényfajainak és vegetációjának tanulmányozásához. Studia Botanica Hungarica 11: 83-106.

VAJDA, L. \& ORBÁN, S. (1976). Vorarbeiten einer Moosflora des SemenicGebirges. Studia Botanica Hungarica 10: 115-118.

\section{7}

ORBÁN, S. (1977). Die Dynamik von Moosgesellschaften im Hortobágy National Park. Congress International de Bryologie. Bryophytorum Bibliotheca 13: 661-680.

ORBÁN, S. (1977). Moss-arealgeographischen Studien aus dem Gebiet der Karpaten und im Karpaten becken V. Studia Botanica Hungarica 12: 4154.

ORBÁN, S. (1977). Studies on African Calymperaceae I. Acta Botanica Hungarica 23: 167-177.

\section{8}

Orbán, S. (1978). Studies on African Calymperaceae II. Acta Botanica Hungarica 24: 113-120.

1979

ORBÁN, S. (1979). Bericht über die erste Konferenz des MoosforscherArbeitsgemeinschaft in den sozialistischen Landern. Abstracta Botanica 5(Suppl. 3): 1-6.

\section{0}

ORBÁN, S. (1980). Bryophyta-Mohák. In: Soó, R (ed.): A magyar flóra és vegetáció rendszertani-növényföldrajzi kézikönyve. VI. Akadémiai Kiadó, Budapest. pp. 20-36.

ORBÁN, S. (1980). Adatok a Bükki Nemzeti Park (BNP) mohaflórájának ismeretéhez. Folia Historico-Naturalia Musei Matraensis 6: 71-72.

\section{1}

FEHÉR, G. \& ORBÁN, S. (1981). A bükki "Őserdő" korhadó fáinak mohacönológiai vizsgálata. Folia Historico-Naturalia Musei Matraensis 7: 15-28.

HAJDÚ, L. \& ORBÁN, S. (1981). Über die grüne Pflanzenwelt der BaradlaHöhle bei Aggtelek. Studia Botanica Hungarica 15: 5-17. 
ORBÁN, S. (1981). Studies on African Calymperaceae III. Conspectus of the African species of Syrrhopodon Schwaegr. Acta Botanica Hungarica 27: 169-177.

\section{2}

BAKAláR, SNÉ, ORBÁN, S., SubA, J. \& TAKÁCS, B. (1982-1983). A Cypripedium calceolus L. feltárt termőhelyei a Bükk hegységben és környékén. Folia Historico-Naturalia Musei Matraensis 8: 77-92.

ORBÁN, S. (1982). Dr. Simon Tiborné. Szervezeti Életünk 8: 60-62.

ORBÁN, S. (1982). Floristical and chorological investigations on bryophytes in Hungary. Lejeunea 107: 30-31.

ORBÁN, S. (1982). Miskolcról induló túrák. Kirándulási kalauz 1. Túrák a Bükk-hegységben, pp. 93-111.

ORBÁN, S. (1982). Oktató-nevelő munka. Az Egri Tanárképző Főiskola Évkönyve 1979-1982, pp. 62-64.

ORBÁN, S. (1982). The bryoflora of the Hortobágy National Park and the adjoining conservation areas. In: SzUJKó-LACZA (ed.): The flora of the Hortobágy National Park. Akadémiai Kiadó, Budapest, pp. 97-103.

SUBA, J., KISZELY-VÁMOSI, A., LÉGRÁDI, GY. \& ORBÁN, S. (1982). Examination of the photosynthetic fixation $14 \mathrm{CO}_{2}$ on bryophyte and lichen species. Acta Botanica Academiae Scientiarum Hungaricae 28: 151-191.

\section{3}

ORBÁN, S. \& VAJDA, L. (1983). Magyarország mohaflórájának kézikönyve. Akadémiai Kiadó, Budapest. 580 p.

ORBÁN, S. (1983). The fourth meeting of Central and East European bryologists. The Bryological Times 24: 7.

ORBÁN, S. (1983). A magyarországi mohák stratégiái, összefüggésük a környezet ökológiai és cönológiai jellemzőivel. Kandidátusi értekezés, MTA Budapest, $115 \mathrm{p}$.

\section{4}

ORBÁN, S. \& Galambos, I. (1984). Crossidium crassinerve (De Not.) Jur. new member of the Hungarian bryoflora. Bryologische Beiträge 3: 23-27.

ORBÁN, S. (1984). A magyarországi mohák stratégiái és T, W, R értékei. Acta Academiae Paedagogicae Agriensis Nova Series: Sectio Biologiae 17: 755-765.

ORBÁN, S. (1984). Sokszínű, nagy virágú íriszek. Népújság.

\section{5}

ORBÁN, S. (1985). A Sár-hegy mohaflórája. Folia Historico-Naturalia Musei Matraensis 10(1): 39-46. 
ORBÁN, S. (1985). Bryophyta-Mohák. In: PRISZTER Sz. .(ed.): A magyar flóra és vegetáció rendszertani és növényföldrajzi kézikönyve. VII. Akadémiai Kiadó, Budapest. pp. 29-31.

ORBÁN, S. (1985). Preface In: ORBÁN, S. \& PODANI, J. (eds.): The proceedings of the 4th CEBWG Bryol. Conf. Abstracta Botanica 9(Suppl. 2): 5-6.

ORBÁN, S. (1985). Studies on African Calymperaceae IV. Distribution of the African species of Syrrhopodon Schwaegr. Abstracta Botanica 9(Suppl. 2): 99-107.

ORBÁN, S. (1985). Studies on African Calymperaceae IV. Distribution of the African species of Syrrhopodon Schwaegr. Acta Academiae Paedagogicae Agriensis Nova Series: Sectio Biologiae 17(1): 6.

ORBÁN, S. (1985). The fourth meeting of Central and East European bryologists, 2nd Circular. The Bryological Times 30: 9.

ORBÁN, S. (1985). Tudományos életünk sikeres esztendeje. Szervezeti Életünk 10(1): 59-60.

\section{6}

ORBÁN, S. (1986). A tudományos bizottság munkájáról. Az Egri Tanárképző Fơiskola Évkönyve 1982-1985, pp. 86-88.

REESE, W. D. \& ORBÁN, S. (1986). Notes on the taxonomy of African Syrrhopodon. Abstracta Botanica 10: 349-355.

REESE, W. D. \& ORBÁN, S. (1986). Syrrhopodon incompletus Schwaegr. var. incompletus (Musci: Calymperaceae) disjunct between the American and African bryoflora. The Bryologist 89: 213-214.

\section{7}

BAKAlár, SnÉ, KisZely-VÁmosi, A., ORBÁN, S., SuBA, J. \& TAKÁCS, B. (1987). Az Esztramos-hegy bányászattól érintetlen gerincének florisztikai viszonyai. Acta Academiae Paedagogicae Agriensis Nova Series: Sectio Biologiae 18(2): 35-50.

ORBÁN, S. (1987). László Vajda 1890-1986. (obituary) The Bryological Times 41: 6.

ORBÁN, S. (1987). Report on the proceedings of IAB Bryoecological Conference and CEBWG Bryological Conference. The Bryological Times 41: 5 .

ORBÁN, S. (1987). Studies on African Calymperaceae V. Syrrhopodon species collected by S. Lisowski in tropical Africa. Acta Academiae Paedagogicae Agriensis Nova Series: Sectio Biologiae 18: 81-87.

ORBÁN, S. (1987). The use of bryophytes for ecological comparison of vegetational units and of habitats. In: Pócs, T., Simon, T, TUBA, Z. \& PoDANI, J. (eds.): Proceedings of the IAB Conference of Bryoecology. Symposia Biologica Hungarica 35: 379-404. 


\section{9}

Kiszely-VÁmosi, A., Marschall, Z., SubA, J. \& Orbán, S. (1989). A Bükk hegység északi peremhegyeinek florisztikai és cönológiai jellemzése. Acta Academiae Paedagogicae Agriensis Nova Series: Sectio Biologiae 19(6): 135-185.

ORBÁn, S. (1989). Analysis of some plant communities based on bryophyte layer. Acta Academiae Paedagogicae Agriensis Nova Series: Sectio Biologiae 19(6): 197-209.

Orbán, S. (1989). Nesze neked, Egri Egyetem. Heves Megyei Népújság.

ORBÁn, S. (1989). The coenological and ecological connections of the life strategies of bryophytes. Proceedings of the Sixth CEBWG Meeting, Liblice, Czechoslovakia. pp. 172-179.

ORBÁN, S. (1989). The intraspecific categories of Syrrhopodon prolifer Schwaegr. in Africa. Proceedings of the Sixth CEBWG Meeting, Liblice, Czechoslovakia, pp. 269-271.

\section{0}

ORBÁN, S. \& REESE, W. D. (1990). Syrrhopodon prolifer (Musci: Calymperaceae): A World View. The Bryologist 93(4): 438-444.

ORBÁN, S. (1990). Coenological connections of the life strategies of bryophytes. 7th CEBWG Meeting, Apatity, Soviet Union, Abstracts, p. 49.

ORBÁN, S. (1990). Life strategies of endangered bryophytes in Hungary. Conference of Endangered Bryophytes, Uppsala, Abstracts, p. 19.

ORBÁN, S. (1990). Mézesmadzag és epeömlés. Azaz miért nem kedvel engem a Bori? Heves Megyei Népújság.

\section{1}

ORBÁN S. (1991). Összefoglaló vélemény a Felsőoktatási Törvény tervezetéről. Magyar Felsőoktatás 5: 8-9.

Orbán S., MARSChall, Z., KóNYA, E., LÉGRÁdy, Gy., SuBA, J., KáRÁSZ, I., TUBA, Z., VARGA, J. \& DÓSA, G. (1991). A mohák életstratégiái, vizsgálatának eredményei II. Magyar Ökológus Kongresszus. Poszterek Összefoglalói. PATE Georgikon Keszthely, p. 110.

ORBÁN, S. (1991). A mohakutatás alakulása hazánkban az utóbbi évtizedekben. Budapest-Szombathely. BioTár VII., pp. 22-23.

ORBÁN, S. (1991). A mohakutatás alakulása hazánkban az utóbbi évtizedekben. Botanikai Közlemények 78: 29-32.

ORBÁN, S. (1991). Mohák. In: Simon T. (ed.): Baktérium-, alga-, gomba-, zuzmó- és mohahatározó. Tankönyvkiadó, Budapest, pp. 677-778.

ORBÁN, S. (1991). OTKA Témapályázat zárójelentése. MTA részére, 8 p.

ORBÁN, S. (1991). The dynamics of the bryophyte layer of disturbed communities on the basis of life strategy examinations. 34th IAVS Symposium on "Mechanisms in Vegetation Dynamics", Abstracts p. 92. 
ORBÁN, S., MARSCHALl, M. \& MÉSZÁRos I. (1991). Moha és talaj kölcsönhatások erdő és gyeptársulásokban. II. Magyar Ökológus Kongresszus. Poszterek összefoglalói. PATE Georgikon Keszthely, p. 93.

ORBÁN, S., MARSCHALL, Z., SUBA J. \& VoJTKó A. (1991). Vegetációtanulmányok a Bükk hegységben. A Messzelátó-hegy, Ördög-hegy növényzete. Acta Academiae Paedagogicae Agriensis Nova Series: Sectio Biologiae 20: 139159.

\section{2}

ORBÁN, S. (1992). A tanárképző főiskolák, valamint a tudományegyetemek vezetőinek állásfoglalása az egységes egyetemi szintü tanárképzés ügyében. Magyar Felsőoktatás 7: 16.

ORBÁN, S. (1992). Life strategies in endangered bryophytes in Hungary. Biological Conservation 59: 109-111.

\section{3}

ORBÁN, S. (1993). Állásfoglalás az egyetemi szintű tanárképzés ügyében. Hírlevél 1(3): 5-6.

ORBÁN, S. (1993). Előszó (Eszterházy Károly emlékezete). Acta Academiae Paedagogicae Agriensis Nova Series: Sectio Biologiae 21: 5-7.

ORBÁN, S. (1993). Taxonomic results of the BRYOTROP expedition to Zaire and Rwanda 18., Calymperaceae. Tropical Bryology 8: 171-173.

\section{4}

ORBÁN, S. (1994). A magyarországi mohászat rövid története. Studia Botanica Hungarica 25: 101-102.

ORBÁN, S. (1994). A tanárképző főiskolák állásfoglalása az ötéves egyetemi szintű képzés bevezetésével kapcsolatban 1995-től 2000-ig. Hírlevél 1(8): 30.

ORBÁN, S. (1994). Reform ideas in the Education System of Hungary: Education and Training in Europe. Unterricht, Studium, Fortbildung 8: 205-212.

ORBÁN, S. (1994). Reformideen im ungarischen Erziehungssystem: Erziehung und Ausbildung in Europa. Unterricht, Studium, Fortbildung 8: 69-79.

\section{5}

ORBÁN, S. \& TóTh, Z. (1995). Mohák. In: JÁRAI-Komlódi M.(ed.): A magyar flóra. Pannon Enciklopédia, Magyarország növényvilága. Dunakanyar 2000 Kiadó, Budapest, pp. 100-109.

ORBÁN, S. (1995). Biometria fóiskolai hallgatók számára. Jegyzet. Kézirat. EKTF Kiadó, Eger. 84 p. 
ORBÁN, S. (1995). East African bryophytes, XV. Calymperaceae species collected in Seychelles Islands in 1993. Fragmenta Floristica et Geobotanica 40(1): 279-287.

ORBÁN, S. (1995). Mohák szerepe az erdei társulásokban, társulások értékelése mohaflórájuk alapján. Tilia 1: 185-198.

ORBÁN, S. (1995). Studies on African Calymperaceae, VI: New data to continental Africa and Madagascar. Acta Botanica Hungarica 39(3-4): 227-234.

\section{7}

ORBÁN, S. (1997). Epiphyllous Calymperaceae species. Abstracta Botanica 21(1): 119-121.

\section{8}

ORBÁN, S. \& VADON, L. (1998). Az Intézmény tudományos életének fejlődése és jelenlegi helyzete, föiskolánk külkapcsolatai. 50 éves a Tanárképzés Egerben. EKTF, Líceum Kiadó, Eger, pp. 119-131.

PÉNZESNÉ KÓNYA, E. \& ORBÁN, S. (1998). A Bükk hegység radiolarit alapkőzetű területeinek mohaflórája. Kitabelia 3(2): 357-359.

\section{9}

ORBÁN, S. (1999). Általános bryológia. Líceum Kiadó, Eger, 380 p.

ORBÁN, S. (1999). Az afrikai Calymperaceae család (Bryophyta-Bryopsida) taxonómiai monográfiája. MTA doktori értekezés. MTA Budapest, 207 p.

\section{0}

Dulai, S., Pócs, T., ORbán, S., Lehoczki, E. \& Molnár, I. (2000). Some photosynthetic characteristics of an indigenous (Cyathea glauca) and an introduced (Psidium cattleyanum) plant species in Reunion island. Plant Physiology And Biochemistry 38: 237.

ORBÁN, S. (2000). A főiskolai kutatások helyi, országos és nemzetközi szerepe. MTESZ Tudományos Közleményei 3: 16-25.

ORBÁN, S. (2000). A löszfalak moháinak életstratégiái (Life strategies of bryophytes of loess cliffs). Acta Biologica Debrecina-Supplementum Oecologica Hungarica 11(1): 117.

ORBÁN, S. (2000). Calymperes venezuelanum a Newly Discovered American-African Disjunct Element in the Flora of Madagascar. The Bryologist 103(1): 145-146.

ORBÁN, S. (ed., 2000). 50 éves a biológiaoktatás Egerben (Magyar Tudomány Napja '99 Konferencia előadásainak összefoglalói). 1999.11. 03-05. Nyíregyháza-Eger.

PÉNZESNÉ KóNYA, E. \& ORBÁN, S. (2000). A Bükk hegység radiolarit alapkőzetű területeinek mohaflórája II. Kitaibelia 5(1): 125-130. 


\section{1}

Dulai, S., Orbán, S., Horváth, F., Csizi, K., Marschall, M. \& Molnár, I. (2001). A növekvő tilakoid energizáltság és a csökkenő víztartalom hatása a fotoszintetizáló apparátus hőmérsékleti stabilitására Homalothecium lutescensben in vivo. IV. Magyarországi Fotoszintézis Találkozó, 2001.05. 07-08., Szeged, p. 5.

ORBÁN, S. (2001). Az Eszterházy Károly Főiskola tudományos munkájáról. In: ZıMÁNYI, Á. (ed.) Az Eszterházy Károly Főiskola évkönyve 1996-2000, Líceum Kiadó, Eger, pp. 45-48.

ORBÁN, S. (2001). Biometria főiskolai hallgatók számára. Jegyzet, 2. kiadás. Líceum Kiadó, Eger, 84 p.

\section{2}

BÁlinT, L. \& ORBÁN, S. (2002). Két új faj Románia mohaflórájában. Acta Academiae Paedagogicae Agriensis Nova Series: Sectio Biologiae 23: 3740.

Dulai S., Pócs, T., Orbán, S., LehoczKi, E. \& MolnáR, I. (2002). The Photosynthesis-Ecophysiological Characterisation of an Indigenous (Cyathea glauca Bory) and an Introduced (Psidium cattleianum Sabine) Plant Species in Reunion Island. Acta Academiae Paedagogicae Agriensis Nova Series: Sectio Biologiae 23: 155-163.

Dulai, S., Horváth, F., ORbÁN, S., DARKó, É., CSIZI K. \& MolnáR, I. (2002). Water deficit under continuous light enhances the thermal stability of photosystem II in Homalothecium lutescens moss (Proceedings of the 7th Hungarian Congress on Plant Physiology.) Acta Biologica Szegediensis 46(3-4): 159-160.

JAKUCS, E., NAÁR, Z., SZEDLAY GY. \& ORBÁN, S. (2002). VA-type and septate endophytic fungi in Hypopterygium mosses. Cryptogamie Mycologie 24: 27-37.

ORBÁN, S. \& BÁLINT, L. (2002). Új adatok a Hargita-hegység mohaflórájához. Folia Historico Naturalia Musei Matraensis 26: 59-65.

ORBÁN, S. (2002). A löszfalak moháinak életstratégiái. In: SALAMON-ALBERT, É. (ed.): Magyar botanikai kutatások az ezredfordulón: Tanulmányok Borhidi Attila 70. születésnapja tiszteletére. PTE Növénytani Tanszék, Pécs, pp. 581-588.

ORBÁN, S. (2002). Alkalmazott matematika környezetvédelmi technológusok számára. Phare HU9705-0203-0008 sz. projekt, Eger, 145 p.

ORBÁN, S. (ed.) (2002). Az Eszterházy Károly Főiskola tudományos közleményei, XXIII: Tanulmányok a biológiai tudományok köréből Eger: Eszterházy Károly Főiskola. Acta Academiae Paedagogicae Agriensis Nova Series: Sectio Biologiae 23.

PÉnzesné Kónya E., ORBÁN, S., B. Sütō, I. \& VARGA J. (2002). The Process of Bryophyte-Lichen Succession on Solidified Lava with Different Ages on 
the Isle of Reunion. Acta Academiae Paedagogicae Agriensis Nova Series: Sectio Biologiae 23: 163-170.

Pócs, T., Geissler, P., Sass-Gyarmati, A., Kis, G. \& Orbán, S. (2002). The bryophytes collected in the Réserve Spéciale de Manongarivo, Madagascar (Chapter 3.) In: GAUTIER L. \& GoODMAN, X. (eds.) Inventaire Floristique et Faunistique de la Réserve Spéciale de Manongarivo (NW Madagascar). Genf: Conservatoire et jardin botaniques de la ville de Genève. pp. 4176.

Pócs, T., Goia, I., Kis, G., Orbán, S., Sass-Gyarmati, A. \& van Zanten, B. O. (2002). Hilpertia velenovsky (Schiffn.) Zander and other pottioid mosses (Bryophyta) new to Romania. Studies on the cryptogamic vegetation on loess cliffs, IX. Contributii Botanice 37: 13-24.

\section{3}

ORBÁN, S. (2003). Mohák. In: Simon, T. (ed.): Baktérium-, alga-, gomba-, zuzmó- és mohahatározó. Nemzeti Tankönyvkiadó, Budapest, pp. 715820.

Molnár, I., Orbán, S., Pócs T., Sass-Gyarmati, A., Lehoczi, E. \& Dulai, S. (2003). Photosynthetic responses of Mastigophora diclados (Brid.ex Web.) Nees ecotypes of excess light in consequence of their microhabitats in Reunion Island: a fluorescens induction study. Acta Academiae Paedagogicae Agriensis Nova Series: Sectio Biologiae 24: 215235.

ORBÁn, S. (2003). Pócs Tamás, a trópusi bryológus. Acta Academiae Paedagogicae Agriensis Nova Series: Sectio Biologiae 24: 11-19.

ORBÁN, S. \& SASS-GYARMATI, A. (2003). Új adatok a Retyezát hegység mohaflórájához. Acta Academiae Paedagogicae Agriensis Nova Series: Sectio Biologiae 24: 137-147.

GÁL, L., BÁLO, B., ORBÁN, S., KISS, A. PóK, T. \& T. GÁL, T. (2003). Development of the controlled apellation origin system of Egri Bikaver. Colloque International Paysages de Vignes et de Vins. Abstracts, p. 35.

GÁL, L., BÁLO, B., ORBÁN, S., KISS, A., PóK, T. \& GÁL, T. (2003). Az Egri Bikavér mint hungaricum versenyképességének növelésével és eredetvédelmével kapcsolatos kutatások és technológiai fejlesztések. Egri Bikavér Bulletin 1: 6.

Orbán, S. (2003). In honour of the seventy-year-old Tamás Pócs. Acta Botanica Hungarica 45(3-4): 227-258.

GÁL, L., BÁLO, B., ORBÁN, S., KISS, A. PóK, T. \& GÁL, T. (2003). Development of appellation origin controll system of Egri Bikavér. Paysages de Vignes et de Vins. Colloque International Abbaye Royale de Fontevraud (Proceedings). pp. 39-42.

ORBÁN, S. \& Tóth, Z. (2003). Mohák. In: JÁRAI-KomlóDI, M. (ed.): A magyar flóra. Magyarország növényvilága. Pannon Enciklopédia, Urbis Kiadó, Budapest, pp. 100-109. 
BÁLINT, L. \& ORBÁN, S. (2003). Bryofloristical researches of Harghita Mountains. Contributii Botanice 38(1): 13-18.

\section{4}

Dulai, S., Csizi, K., Sass-Gyarmati A., Orbán, S. \& Molnár, I. (2004). Combined effects of Thylakoid Energisation Level and Water Deficit on Thermal Stability of Photosystem II in a Dessication Tolerant Moss. Acta Academiae Paedagogicae Agriensis Nova Series: Sectio Biologiae 25: 127138.

ORBÁN, S. (2004). A biodiverzitás és az ember környezetformáló szerepe In: RENN, O. (ed.) Fenntartható fejlödés a 21. században: Tudományos Közlemények 7. 2004.11.11., Eger, Műszaki és Természettudományi Egyesületek Szövetsége, pp. 19-23.

ORBÁN, S. \& SASS-GYARMATI, A. (2004). Új adatok az Upponyi-hegység mohaflórájához. Acta Academiae Paedagogicae Agriensis Nova Series: Sectio Biologiae 25: 43-48.

ORBÁN, S. (2004). Biometria föiskolai hallgatók számára. EKF Líceum Kiadó, Eger, 125 p.

ORBÁN, S. (2004). A biodiverzitás és az ember környezetformáló tevékenysége. Tudományos Közlemények (MTESZ Heves Megyei Szervezete) 7: 19-23.

\section{5}

Molnár, K., Sass-Gyarmati, A., Kis, G., Orbán, S., PÉnzesné Kónya E. \& SÁNTHA, T. (2005). Mohák, zuzmók és nagygombák florisztikai feldolgozása acidofil erdőállományokban a Bükk hegység területén. In: LENGYel, Sz., Sólymos P. \& KLEIN Á. (ed.): III. Magyar Természetvédelmi Biológiai Konferencia Program és Absztrakt kötete, 2005.11.03-06. Eger, Magyar Biológiai Társaság, p. 169.

ORBÁN, S. (2005). Some records to the Australian Calymperaceae. Acta Academiae Paedagogicae Agriensis Nova Series: Sectio Biologiae 26: 6569.

ORBÁn, S. (2005). Taxonomy and diversity of the African non-leucobryoid Calymperaceae species. Proceedings of 17th International Botanical Congress, 2005.07.17-23.,Vienna, Austria, p. 459.

PÉnzesné Kónya, E., Orbán, S., SAss-Gyarmati, A. \& Molnár, K. (2005). Special habitat types and new floristical data of the cryptogams in the area of Bükk National Park. Conservation Ecology of Cryptogams, Midsweden University, 2005.11.21-25., Sundsvall, Sweden.

SASs-Gyarmati, A. PócS, T. \& Orbán, S. (2005). Contribution to the knowledge of the bryoflora of Natural Reserve Detunata (Metaliferi Mountains, Romania) Studia Botanica Hungarica 36: 123-130.

SAss-Gyarmati, A., MolnÁr, K., Orbán, S., Pócs, T. \& Erzberger, P. (2005). The cryptogamic flora of the Zgurasti Cave and surroundings. (Apuseni 
Mountains, Romania). Proceedings of 17th International Botanical Congress, 2005.07.17-23.,Vienna, Austria, p. 619.

\section{6}

Orbán, N., KisS, A., DrávuCZ, M. GÁL, L. \& ORBÁN, S. (2006). Comparative study on selected polyphenol content in red wines of Eger (Hungary). Acta Alimentaria Hungarica 35(4): 465-477.

ORBÁN, S. (2006). Acidofil erdei és sziklai társulások mohaökológiai vizsgálata a Bükk hegységben In: KALAPOS, T. (ed.) Jelez a flóra és a vegetáció. A 80 éves Simon Tibort köszöntjük. Budapest, Scientia, pp. 33-40.

ORBÁN, S. (2006). Barnahátú zsemlegomba (Scutiger oregonensis Murrill 1912, Polyporales, Albatrellaceae) védett gombafaj a Bükk hegységben Acta Academiae Paedagogicae Agriensis Nova Series: Sectio Biologiae 33: $51-54$.

ORBÁN, S. (2006). Studies on African Calymperaceae, VII.: New records and identification key of species of the non-leucobryoid Calymperaceae species of Madagascar. Tropical Bryology 28: 49-58.

SÁNTHA, T. \& ORBÁN, S. (2006). Nagygombák a Bükk hegységből Acta Academiae Paedagogicae Agriensis Nova Series: Sectio Biologiae 33: 5568.

\section{7}

BÁlinT, L. \& ORBÁN, S. (2007). A Hargita-hegység, a Csíki-havasok és a Nagyhagymás brioflorisztikai kutatások áttekintése. A Csíki Székely Múzeum Évkönyve 3: 465-476.

ORBÁN, S. (2007). A mohák törzsei. In: Tuba Z., SZERDAHELYI T., ENGLONER A. \& NAGY J. (eds.) Botanika: Bevezetés a növénytanba, algológiába, gombatanba és funkcionális növényökológiába. Tankönyvkiadó, Budapest, pp. 361-381.

\section{8}

BOROSNÉ KENYERES, J. \& ORBÁN, S. (2008). List of the scientific publications of Ádám Boros 1900-1973 (Verzeichnis der wissenschaftlichen Publikationen von Ádám Boros 1900-1973). In: SzABó, I. L. \& SzABó L. GY. (eds.): Boros Ádám Breviárium. Pannon Egyetem Georgikon Kar, Keszthely, pp. 159-170.

ORBÁN, S. (2008). A magyarországi mohászat rövid története. In: SZABó, I. L. \& Szabó L. Gy. (eds.): Boros Ádám Breviárium. Pannon Egyetem Georgikon Kar, Keszthely, pp. 57-59.

ORBÁN, S. (2008). Acidofil erdőtársulások mohavegetációjának vizsgálata a Bükk hegységben. Abstract, Aktuális flóra és Vegetációkutatás a Kárpátmedencében VIII. konferencia. Kitaibelia 13(1): 123. 
Orbán, S., PÉnzesné KónYA, E. \& SASS-Gyarmati, A. (2008). Acidofil erdőtársulások kriptogám szinúziumainak florisztikai, cönológiai és ökológiai vizsgálata a Bükk hegységben. Abstract, Aktuális flóra és Vegetációkutatás a Kárpát-medencében VIII. konferencia. Kitaibelia 13(1): 183.

\section{9}

ORBÁN, S. (2009). Acidofil erdőtársulások moháinak életstratégiái a Bükk hegységben. 8. Magyar Ökológus Kongresszus 2009, Előadások és Poszterek összefoglalói, Szeged, p. 169.

ORBÁN, S. (2009). Mitthyridium constrictum (Sull.) Robins., new to Thailand and other Calymperaceae (Bryophyta) species from Phuket and adjacent region (Thailand). Acta Academiae Paedagogicae Agriensis Nova Series: Sectio Biologiae 36: 21-24.

Orbán, S., PÉnZesné Kónya, E. \& SASS-Gyarmati A. (2009). Radiolarit és agyagpala alapkőzeten kialakult acidofil erdőtársulások kriptogám vegetációjának leírása a Bükk hegységből. Acta Academiae Paedagogicae Agriensis Nova Series: Sectio Biologiae 36: 3-20.

Orbán, S., PÉnZesné KónYA, E. \& SASS-Gyarmati, A. (2009). Mészkerülő erdőtársulások domináns mohafajainak mintázat vizsgálata. 8. Magyar Ökológus Kongresszus 2009, Szeged. Előadások és Poszterek összefoglalói, Szeged, p. 170.

Sass-Gyarmati, A., Molnár, K., Orbán, S., Pócs, T. \& Erzberger, P. (2009). The cryptogamic flora of the Zgurăşti sinkhole system and its surroundings (Apuseni Mountains, Romania). Kanitzia 16: 25-44.

\section{0}

ORBÁN, S. (2010). Moha stratégia-ökológiai kutatások. Botanika Hete, Eszterházy Károly Főiskola, 2010. 05.21., Eger, p. 3.

\section{1}

ORBÁN, S. (2011). Acidofil erdők moháinak diverzitása. In: ORBÁN, S. \& ANTAL, K. (eds.) Magyar Tudomány Ünnepe 2011, EKF TTK, Előadások. 2011.11.09. Eger, p. 4.

ORBÁN, S. (2011). Modern ökológiai szemlélet a környezeti nevelésben. In: MIKA J. (ed.) Környezeti Nevelés és Tudatformálás Konferencia, EKF TTK, 2011.12.08., Eger, p. 2.

\section{2}

ORBÁN, S. (2012). Adatok a debreceni Nagyerdő mohaflórájához Calandrella 15: 73-75.

ORBÁN, S. (2012). Kriptogámok (gombák, zuzmók, mohák) védelmének alakulása Magyarországon az elmúlt évtizedekben. In: KISS, Cs. (ed.) 1972-2012 Ember és Bioszféra Konferencia, 2012.02.22., Eger, p. 4. 
2013

ORBÁn, S. \& PÉnZesné Kónya E. (2013). Professor Tamás Pócs the record of his 80 years. Polish Botanical Journal 58(1): 3-30.

PÉnzesné Kónya, E., Orbán, S., Pócs, T. \& SASS-Gyarmati, A. (2013). Az Eszterházy Károly Főiskola megújult herbáriuma (EGR). Acta Academiae Paedagogicae Agriensis Nova Series: Sectio Biologiae 15(1): 5-9.

\section{4}

ORBÁN, S. (2014). Egzotikus Fűszernövények. Eszterházy Károly Főiskola, Eger 146 p.

ORBÁN, S. (2014). Exotic Spices and Herbs. Eszterházy Károly Főiskola, Eger, 148 p.

\section{5}

ORBÁN, S. \& HoRvÁTH, B. (2015). Bélapátfalva környéki erdők nagygombái. In: SzÚCS, P. \& PÉNZESNÉ KóNYA, E. (eds.): III. Aktuális eredmények a kriptogám növények kutatásában, A konferencia előadásainak és posztereinek összefoglalói, 2015.11.17-18., EKF Líceum Kiadó, Eger, p. 43.

ORBÁN, S. (2015). Modern ökológiai szemlélet a környezeti nevelésben. In: MIKA J. \& PAJTÓKNÉ TARI, I. (eds.) Környezeti nevelés és tudatformálás: tanulmányok az Eszterházy Károly Főiskola műhelyeiből. EKF Líceum Kiadó, Eger, pp. 103-112.

ORBÁN, S., UJFALUDI L. \& MiKA, J. (2015). Bolygónk környezeti problémái. In: MIKA J. \& PAJTÓKNÉ TARI, I. (eds.) Környezeti nevelés és tudatformálás: tanulmányok az Eszterházy Károly Főiskola műhelyeiből. EKF Líceum Kiadó, Eger, pp. 17-35.

\section{NEW TAXA DESCRIBED BY SÁNDOR ORBÁN OR NAMED AFTER HIM}

Syrrhopodon subg. Syrrhopodon, Sect. Tricostatae sect. nov., ORBÁN 1977, Acta Botanica Academiae Scientiarum Hungaricae 23: 174.

Syrrhopodon usambaricus Broth. ex Orbán, sp. nov., ORBÁN 1978, Acta Botanica Academiae Scientiarum Hungaricae 24: 8.

Syrrhopodon subg. Syrrhopodon, Sect. Crassimarginatae sect. nov., ORBÁN 1981, Acta Botanica Academiae Scientiarum Hungaricae 27: 170.

Syrrhopodon subg. Hyalolimbatae subg. nov., ORBÁN 1981, Acta Botanica Academiae Scientiarum Hungaricae 27: 170.

Syrrhopodon armatus subsp. insularis (Bizot \& Onr.) comb. et stat. nov. ORBÁn \& REESE 1986, Abstracta Botanica 10: 353.

Syrrhopodon lisowskii sp. nov., ORBÁN 1987, Acta Academiae Paedagogicae Agriensis 18(2): 81. 
Syrrhopodon prolifer Schwaegr. var. hispidocostatus (Renauld et Cardot) comb. et stat. nov. ORBÁN et W.D. REESE 1990. The Bryologist 93(4): 442.

Syrrhopodon prolifer Schwaegr.var. tosaensis comb. et stat. nov. ORBÁN et REESE, 1990. The Bryologist 93(4): 442.

Syrrhopodon prolifer Schwaegr. var. albidus (Thwait \& Mitt.) comb. et. stat. nov. ORBÁN et W.D. REESE 1990. The Bryologist 93(4): 444.

Syrrhopodon mahensis Besch. var. laevis var. nov., ORBÁN 1995, Fragmenta Floristica et Geobotanica 40: 285.

Syrrhopodon mahensis Besch. var. palmarum var. nov., ORBÁN 1995, Fragmenta Floristica et Geobotanica 40: 285.

Syrrhopodon prolifer Schwaegr. var. seychellarum ORBÁN 1995. var. nov. Fragmenta Froristica et Geobotanica 40: 286.

Syrrhopodon pottioides sp. nov., ORBÁN 1995, Acta Botanica Hungarica 39: 232.

Bazzania orbanii sp. nov. Pócs 2011, Acta Biologica Plantarum Agriensis 1: $15-22$.

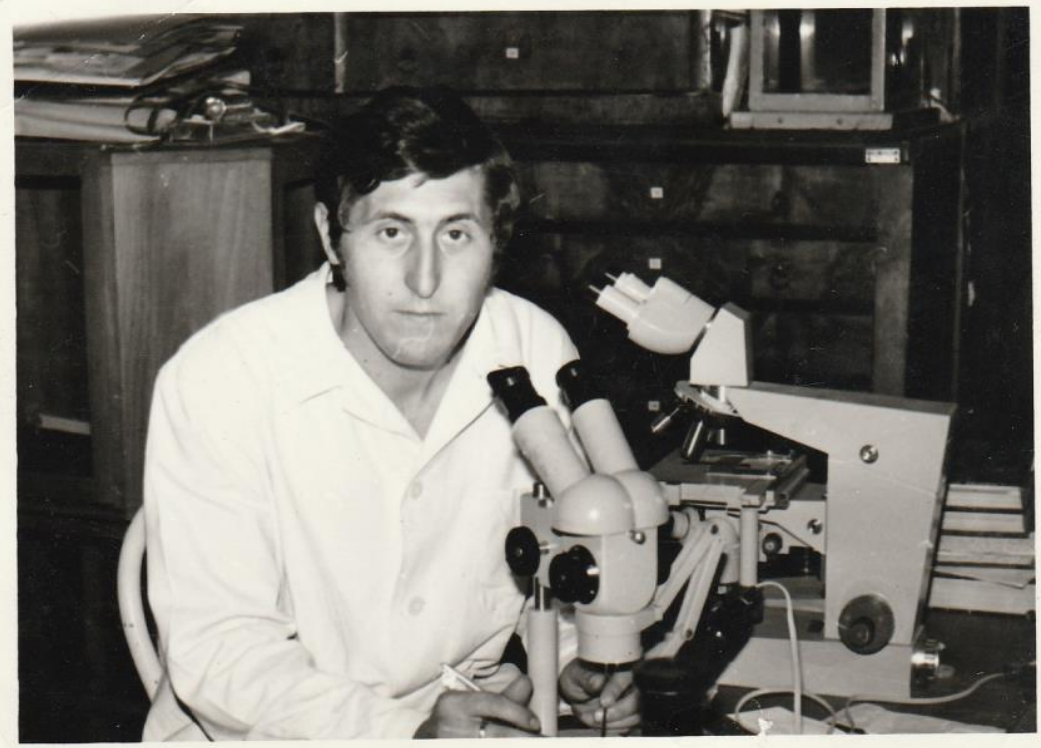

Figure 1. 1972 - Sándor Orbán, young researcher at the Hungarian Natural History Museum 


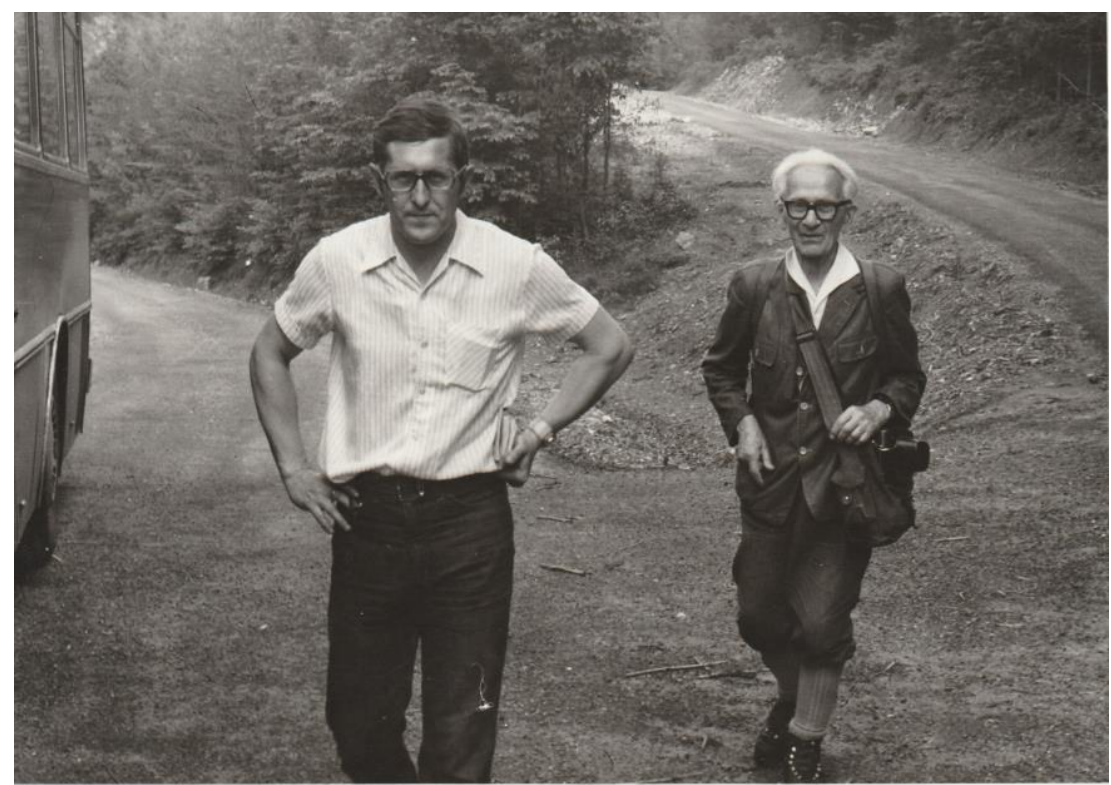

Figure 2. 1978 - Fieldwork together with László Vajda
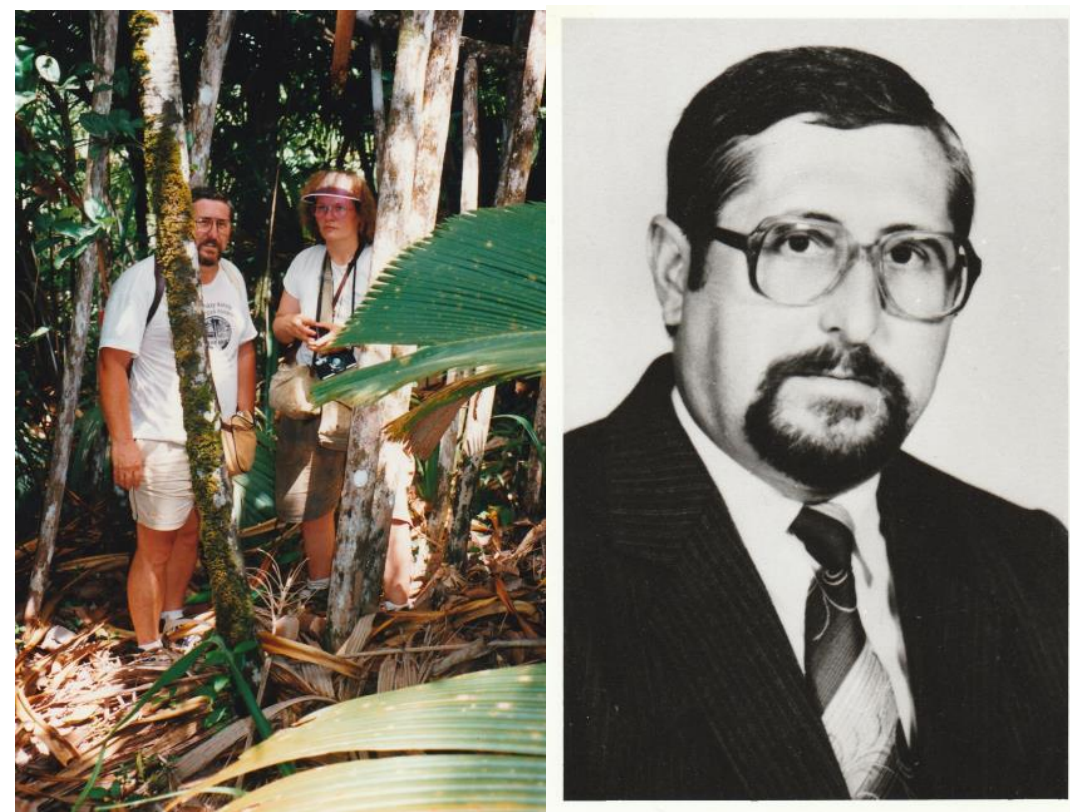

Figure 3. (left) 1993 - Morne Blanc (Seychelles Islands) bryophyte collecting together with Gabriella Kis; Figure 4. (right) Dr. Sándor Orbán: Director of Károly Eszterházy College (1989-1994) 


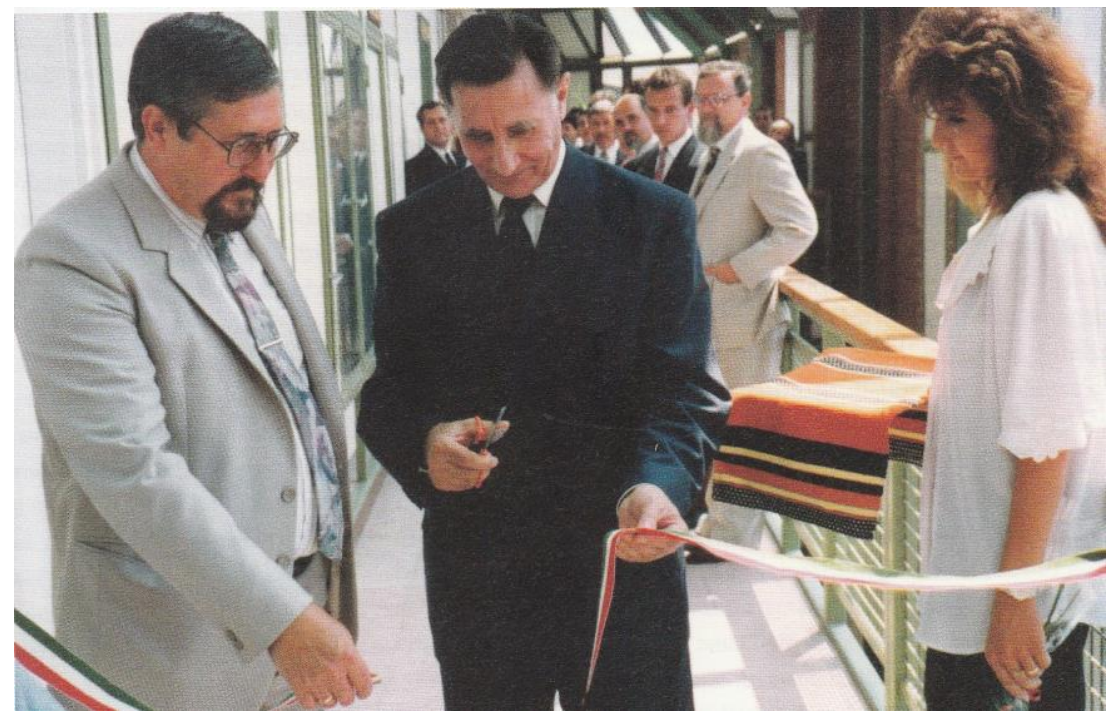

Figure 5. 1991 - Inauguration of Building D -Sándor Orbán (left), Director of the Károly Eszterházy College and Imre Kubovics (middle), Minister of State

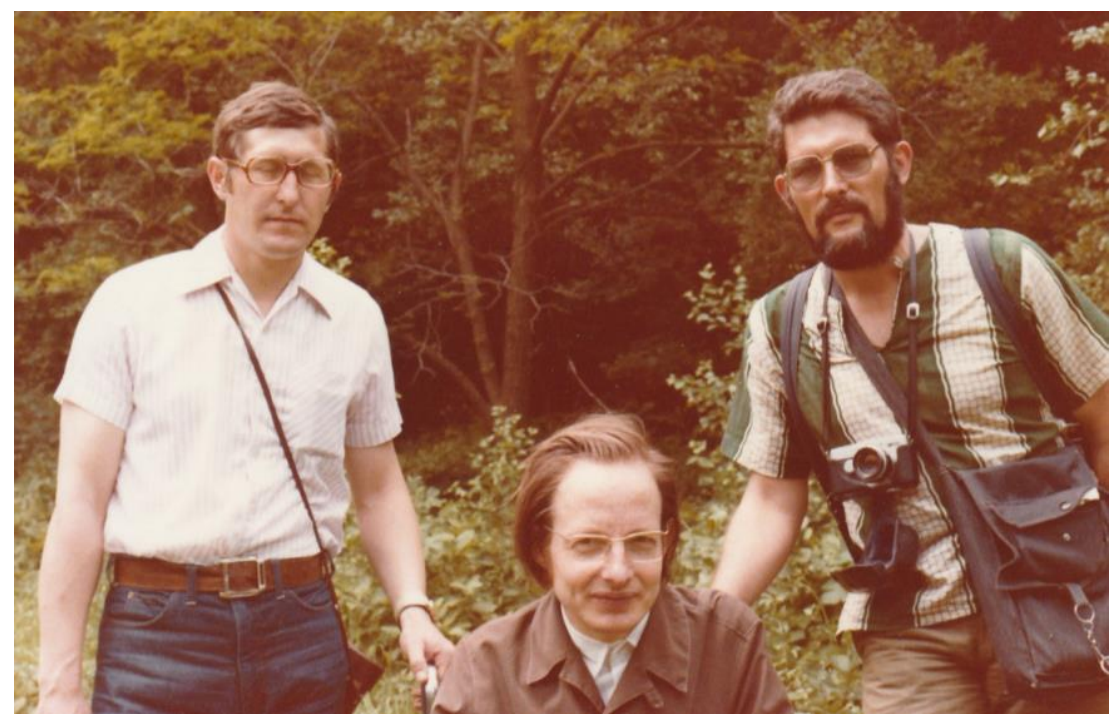

Figure 6. 1978 -Excursion after the 1st Central and East European Bryological Working Group (CEEBWG) meeting in Eger, Hungary (from left: Sándor Orbán, Riclef Grolle and Tamás Pócs) 


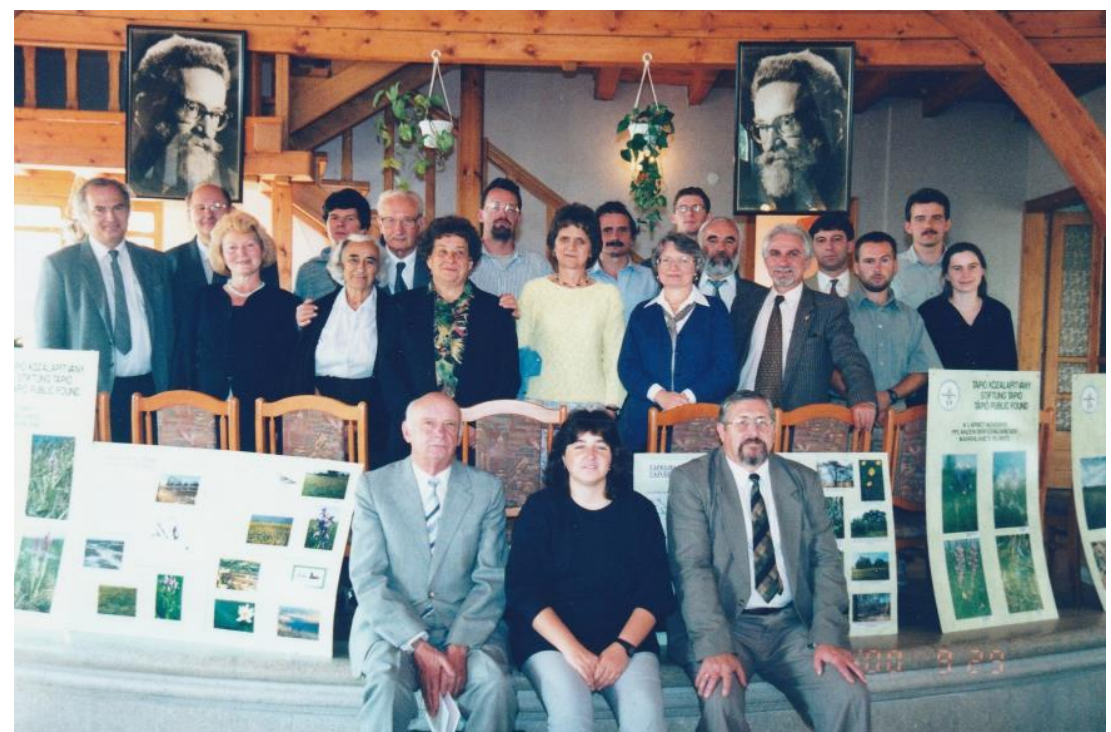

Figure 7. 2000 - Ádám Boros's Centenary Memorial meeting - Tápiószele, Hungary

(submitted: 15.09.2017, accepted: 10.11.2017) 